\title{
Roman Ingarden. Filozof i fotograf - katalog wystawy (Kraków: Muzeum Sztuki Współczesnej w Krakowie MOCAK, 2020, ss. 240)
}

DOI: http://dx.doi.org/10.12775/RF.2021.010

Roman Ingarden marzył o tym, żeby zostać poetą. Myślał też o karierze muzycznej - bardzo dobrze grał na fortepianie, rozwijając swój niewątpliwy talent $\mathrm{w}$ konserwatorium. Jego syn $\mathrm{w}$ biografii ojca napisze, że zamiłowanie do literatury pięknej tkwiło w nim jednak silniej. Kolekcjonował tomy poetyckie, pisał wiersze, a w okresie młodzieńczym otoczenie widziało w nim przyszłego poetę. Jego kariera potoczyła się jednak inaczej - został wybitnym filozofem. Być może głównym powodem takiego biegu wydarzeń było rozczarowanie literatura, która - jak pisat we Wspomnieniach z Getyngi - zraziła go plotkarskim tonem, roztrząsaniem spraw osobistych i pseudofilozoficznymi dywagacjami, które zajmowały według niego dziewięćdziesiąt procent każdej ze studiowanych książek z literatury pięknej ${ }^{1}$. On szukał metody, sposobu badania dzieł wzorem nauk ścisłych, stąd zainteresowania filozofią i późniejszy odwrót w jej kierunku. Matematyka, fizyka - choć traktowane z dystansem przez większość humanistów - doprowadziły go do studiów nad filozofią jako nauką ścisłą i rozwoju zgodnego ze swoją umysłowością. Jego późniejsze zainteresowania sztuką będą już zawsze dopełniane przez filozofię i stworzą spójny obraz przemyśleń i artystycznych poszukiwań. O tych najtrwalszych, bo datowanych na okres od 1942 do 1970, powiada katalog wydany przez Muzeum Sztuki Współczesnej w Krakowie, towarzyszący wystawie „Filozof i fotograf”, która przybliża wybrane zdjęcia wykonane przez Romana Ingardena. Archiwum MOCAK-u mieści ich prawie pięć tysięcy².

Z zamieszczonych w katalogu wystawy, która odbywała się pomiędzy majem a wrześniem 2020, tekstów wynika, że nie zachowało się

1 Por. Roman S. Ingarden, Roman Witold Ingarden. Życie filozofa w okresie toruńskim (1921-1926) (Toruń: Wydawnictwo Naukowe UMK, 2000).

2 Pasja fotograficzna filozofa rozpoczęła się prawdopodobnie w latach trzydziestych, jednak zdjęcia z pierwszego okresu nie znalazły się w archiwum instytucji. 
wiele relacji dotyczących praktyki fotograficznej filozofa. Nie wiemy ani tego, czy zawsze sam wywoływał zdjęcia, ani tego, co sądził o tej dyscyplinie sztuki, ponieważ wprost o niej nie pisał. Możemy się tylko domyślać, że aparat często mu towarzyszył. Wykonywał portrety, autoportrety, studia z martwą naturą. Fotografował sceny rodzinne, życie akademickie, architekturę, wnętrza i przyrodę. Towarzysząca wystawie polsko-angielska publikacja, oprócz reprezentacyjnego zbioru zdjęć, daje czytelnikom cztery ciekawe teksty autorstwa Marii Anny Potockiej, Marleny Nikody, Sebastiana Stankiewicza oraz zebrane przez Potocką wspomnienia Władysława Stróżewskiego na temat filozofa. Każdy z autorów, stosując własne narzędzia poznawcze, drąży jeden temat: dlaczego Roman Ingarden fotografował?

"Czy czasem zachowywał się jak artysta? Jaką sztukę cenił?" - dopytuje Stróżewskiego Potocka, kreśląc ramy portretu psychologicznego filozofa. Opowiadając o swoich prywatnych relacjach ze starszym kolega, krakowski filozof rysuje obraz zdystansowanego, ale wrażliwego na sprawy sztuki człowieka. Wspomina, że Ingarden co prawda raczej nie śledził na bieżąco tego, co dzieje się w galeriach sztuki, za to chętnie i spontanicznie pokazywał innym odbitki swoich zdjęć i, jak mówi Stróżewski, „zależało mu na tym, żeby jego zdjęcia były dobre”3. Często można go było spotkać, kiedy spacerował z aparatem po Plantach. Miał ugruntowane zainteresowania: w muzyce konserwatywny (Chopin, Beethoven) nie wychodził poza Szymanowskiego; jeśli chodzi o malarstwo, ciekaw był nowości. Głośna i intensywna była przyjaźń z Witkacym, zawarta $\mathrm{w}$ okresie toruńskim jego życia. $\mathrm{Z}$ malarzy podobno najbardziej cenił Rembrandta. Gustu i indywidualnych upodobań nie izolował od swoich przemyśleń jako estetyk - często podziwiane obrazy stanowiły przykład do demonstracji szczegółowych zagadnień tej dyscypliny. „Piękno go zachwycało” - powie Stróżewski, ,jednak nie wiem, czy można powiedzieć, że w życiu fascynował się jakimiś ideami. Myślę, że po prostu rzetelnie robił to, co uważał za ważne i słuszne"

Tekst autorstwa Marleny Nikody, zatytułowany „Filozof i fotograf. Próba analizy fotograficznego archiwum Romana Ingardena", mówi przede wszystkim o warsztacie filozofa. Możemy w nim wyczytać wiele na temat tego, jak z punktu widzenia krytyczki wypada dziś ocena pozostawionych kadrów. Niewątpliwie filozof $\mathrm{w}$ fotografii wypracował własny styl, który oprócz zmysłu artystycznego oddaje jego zainteresowania ontologią. Jeśli Roland Barthes zmaga się z fotografią w 1980 roku i pisze przejmującą książkę Światło obrazu. Uwagi o fotografii, widząc w fenomenologii wzór dla prowadzonych przez siebie rozważań, i nazywa tę

3 Roman Ingarden. Filozof $i$ fotograf (Kraków: Muzeum Sztuki Współczesnej w Krakowie MOCAK, 2020), 78.

4 Tamże, 80. 
dyscypliną emocjonalną, to Ingarden - fenomenolog, skupia się na najprostszych elementach. Momenty czasowe, ujęte na wykonanych przez niego zdjęciach jedne po drugich, tworzą złudzenie ruchu, wyglądając jak wykonane w sposób wizualny zadanie ontologiczne. Fotografowane w sekwencjach modelki i modele ukazują złożoność zmiany, zbliżając akt robienia zdjęć do zabaw lub ćwiczeń filozoficznych. Światowa organizacja Word Union of Documentary, definiując, czym jest dokument w 1948 roku (a więc w czasach początku rozwoju fotograficznej pasji Ingardena), rozumie go jako „wszelkie metody rejestrowania na taśmie filmowej rozmaitych aspektów rzeczywistości interpretowanych bądź jako faktyczne sfilmowane, bądź też jako jej wiarygodna i usprawiedliwiona rekonstrukcja" ${ }^{5}$. Ingarden w fotografii był więc przede wszystkim dokumentalistą. Utrwalane przez niego postacie - także on sam - wydają się naturalne, pozbawione sztucznych póz, choć jak pisze Nikody, z pewnością udzielał wskazówek fotografowanym przez siebie osobom. Większość z nich została uchwycona podobnie - z zachowaniem różnorodności perspektywy. W naturalnym dla siebie otoczeniu książek, obrazów oddają życie codzienne środowiska akademickiego. Wśród zdjęć możemy znaleźć uwiecznione wizerunki koleżanek i kolegów po fachu, np.: Marii Gołaszewskiej, Tadeusza Czeżowskiego, Danuty Gierulanki, Izydory Dąbskiej, Tadeusza Kotarbińskiego, Władysława Tatarkiewicza, ale także studentek; fotografie często podkreślają ich młodość i urodę, na które Ingarden był, jak mówił Stróżewski, wrażliwy. Sekwencyjność, wielość perspektywy i naturalność to dominujące cechy stylu Ingardena. Stylu świadomie kształtującego się w oparciu o fotograficzne wprawki np. ćwiczenia z martwej natury, dzięki realizacji których filozof uczył się języka sztuki i podstaw warsztatu.

Z uwagą warto przeczytać znajdujący się w katalogu tekst Anny Marii Potockiej pt. Eksperyment ontologiczno-estetyczny. Śledzący aktywność tej krytyczki, kuratorki i teoretyczki sztuki być może zdziwią się, że do wystawy prac Ingardena doszło w instytucji pod jej kierownictwem. Potocka znana jest z krytycznego podejścia do prac teoretycznych filozofa, z którym w dyskusję weszła w ciekawej książce Estetyka kontra sztuka. Jej tytuł mówi właściwie wszystko. Oddaje także jedną w głównych myśli artykułu towarzyszącego wystawie, którą przytoczę w całości: „Estetyka Romana Ingardena wychodzi z założenia - dość powszechnego wśród polskich estetyków - że to artyści podążają za filozofia, a nie filozofia za sztuką. Estetyk ustala, czym jest sztuka i czym powinna byćc' ${ }^{\prime \prime}$. Jej tekst krąży wokół pytania, na które z autopsji próbował odpowiadać zagadywany przez nią Stróżewski: czy Ingarden czasem zachowywał się jak artysta? Czy w jakimś stopniu jego akademicka i ścisła umysłowość

${ }^{5}$ Marek Hendrykowski, Stownik terminów filmowych (Poznań: ars nova, 1994), 62.

${ }^{6}$ Roman Ingarden. Filozof $i$ fotograf, 12. 
dopuszczała do siebie takie wybryki, jak: myślenie intuicyjne, przeczucia pomagające stworzyć obraz, wzięcie w nawias uczucia pewności wynikającego z oparcia własnej aktywności intelektualnej na metodzie? Chcąc potraktować filozofa jak twórcę, a jego zdjęcia jako dzieła sztuki, trzeba byłoby co najmniej wykazać dwutorowość jego aktywności umysłowej. „Pasja fotograficzna Romana Ingardena nie pasuje do obrazu człowieka, jaki zostawiła nam jego filozofia"7 - stwierdzi Potocka, wyrażając tym samym początkową konsternację wielu odbiorców jego zdjęć. Pełnych wdzięku fotografii "filozofa pewnego" - kogoś, kto dostrzega, przenika i ocenia. Obcując z tą spuścizną, wiemy, że Ingarden jako estetyk radził sobie z opisem odbioru sztuki rzetelnie przeprowadzoną analizą doświadczenia estetycznego. Po obejrzeniu udostępnionych zdjęć trzeba dla sprawiedliwości raz jeszcze wziąć pod lupę jego dyskusję ze współczesnością i przyznać, że prace fotograficzne wyrównują szale, dodając po stronie Ingardena także doświadczenie artystyczne potwierdzające jego wiarygodność na polu myśli o sztuce. Jeśli oskarżane o wszechwiedzę, a więc i pewną butę, podejście do estetyki może prowadzić do konfliktów i kryzysów, wpływając bezpośrednio na poczucie niezrozumienia $\mathrm{w}$ konfrontacji $\mathrm{z}$ artystami, o tyle przypadek Ingardena wydaje się na tym tle wyjątkowy. Trudno oskarżać go o brak orientacji. Jego prace - ujęcia architektury - zbliżają się do abstrakcji. Ze zdjęć - zwłaszcza portretów i fotografii przyrody - promieniuje duża wrażliwość na piękno. Jak można się domyśleć, jako odbiorcy zależało mu na odnalezieniu w sztuce czegoś wartościowego estetycznie, doceniał także rolę kontemplacji, uspokojenia, jakie może nieść ze sobą obcowanie z dziełem. W swojej praktyce artystycznej dawał upust dającemu i tu o sobie znać talentowi, jakby świadomy tego, że systematyczna praca $\mathrm{w}$ filozofii nie jest wystarczającym zajęciem, w którym mógłby się całkowicie zrealizować. Fotografowanie stało się ostatecznie według Potockiej pomostem pomiędzy pracą filozoficzną a sztuką. Analizując doświadczał. Doświadczając - analizował. Krytyczka, określając jego drogę w fotografii jako ciekawą pisze: "Jego aktywność fotograficzna okazała się raczej namysłem nad potencjalnym obrazem niż obrazem skończonym" ${ }^{\prime \prime}$. Być może dlatego filozof nie pokusił się nigdy o zorganizowanie własnej wystawy.

Odpowiedź na pytanie: „dlaczego?” czas pozostawił współczesnym. Zagadnień domagających się rozpatrzenia jest zresztą dużo więcej. Pole problemowe poszerza czwarty tekst katalogu autorstwa Sebastiana Stankiewicza Ingarden - twórca intuicyjny. Oprócz tego najbardziej intrygującego dla wszystkich piszących pytania - Ingarden: filozof czy artysta?, Stankiewicz zwraca uwagę na rolę ujawnionej fotografii dla całości

\footnotetext{
7 Tamże, 6.
}

8 Tamże, 14. 
spuścizny oraz formacji intelektualnej fenomenologów dziś. Wydaje się już niemożliwym, aby wydarzenia artystycznego z MOCAK-u nie włączyć w proces kształcenia przyszłych estetyków idących tropem Romana Ingardena na uniwersytetach i akademiach sztuk pięknych. Towarzyszący wystawie katalog umożliwia zapoznanie się z reprezentatywną próbą zdjęć filozofa. Proponuje także pewną systematyzację dorobku, wyróżniając: autoportrety, portrety, kompozycje, krajobrazy, architekturę, impresje, rośliny, wodę, chmury. Towarzyszący pośmiertnej wystawie katalog znacząco zmienia obraz myśliciela, wpływając także na zmianę oceny jego dorobku intelektualnego oraz dostarczając materiał dla nowych odczytań.

Malina Barcikowska

Polski Instytut Studiów nad Sztuką Świata, Warszawa

ORCID: 0000-0002-2231-2713 e-mail: mbarcikowska76@wp.pl 